\title{
Two freshwater shrimp species of the genus Caridina (Decapoda, Caridea, Atyidae) from Dawanshan Island, Guangdong, China, with the description of a new species
}

\author{
Qing-Hua Chen', Wen-Jian Chen², Xiao-Zhuang Zheng², Zhao-Liang Guo² \\ I South China Institute of Environmental Sciences, Ministry of Ecology and Environment, Guangzhou \\ 510520, Guangdong Province, China 2 Department of Animal Science, School of Life Science and Enginee- \\ ring, Foshan University, Foshan 528231, Guangdong Province, China
}

Corresponding author: Zhao-Liang Guo (zlguo@fosu.edu.cn)

Academic editor: I.S. Wehrtmann | Received 19 November 2019 | Accepted 7 February 2020 | Published 1 April 2020

http://zoobank.org/138A88CC-DF41-437A-BA1A-CB93E3E36D62

Citation: Chen Q-H, Chen W-J, Zheng X-Z, Guo Z-L (2020) Two freshwater shrimp species of the genus Caridina (Decapoda, Caridea, Atyidae) from Dawanshan Island, Guangdong, China, with the description of a new species. ZooKeys 923: 15-32. https://doi.org/10.3897/zookeys.923.48593

\begin{abstract}
A faunistic and ecological survey was conducted to document the diversity of freshwater atyid shrimps of Dawanshan Island. Two species of Caridina that occur on this island were documented and discussed. One of these, Caridina tetrazona sp. nov. is described and illustrated as new to science. It can be easily distinguished from its congeners based on a combination of characters, which includes a short rostrum, the shape of the endopod of the male first pleopod, the segmental ratios of antennular peduncle and third maxilliped, the slender scaphocerite, and the absence of a median projection on the posterior margin. Live individuals of the new species display a unique coloration pattern with four dark blue transverse bands on the body, and can be easily recognized in the field. So far, despite considerable surveying efforts made on neighboring islands, this species has only been found from a small stream on Dawanshan Island, which suggests that it may have a very limited range, probably endemic to Dawanshan Island. Molecular characteristics of the mitochondrial cytochrome c oxidase subunit I (COI) demonstrate that this species shows sufficient interspecific divergence from its congeners, including C. serrata Stimpson, 1860, which was found in four streams on Dawanshan Island, and has been previously reported on the neighboring islands of Hong Kong, Dong'ao, Wailingding, and Guishan.
\end{abstract}

Copyright Qing-Hua Chen et al. This is an open access article distributed under the terms of the Creative Commons Attribution License (CC BY 4.0), which permits unrestricted use, distribution, and reproduction in any medium, provided the original author and source are credited. 


\section{Keywords}

COI, morphology, rice shrimp, systematics, taxonomy

\section{Introduction}

The genus Caridina H. Milne Edwards, 1837, comprising 302 species and mainly present in the Indo-Pacific region, is the most diversified genus of the Atyidae (De Grave et al. 2015; De Mazancourt et al. 2018). Collecting evidence-based information is the foundation for addressing urgent global challenges in biodiversity conservation and sustainable management of native species. The critical knowledge gaps in the taxonomy, population and distribution patterns have to be filled before any decisions can be taken on biologically meaningful and effective conservation management. The atyid fauna of Dawanshan Island has not been properly surveyed. In order to better understand the diversity of the freshwater atyid fauna in the Dawanshan Island, an intensive field survey was carried out in June 2017. The results show that there are two species of atyid shrimps, Caridina tetrazona sp. nov. and C. serrata Stimpson, 1860.

The Wanshan Islands are located in the Pearl River Estuary, Zhuhai, Guang-

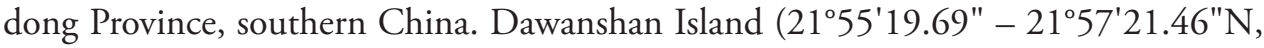
$113^{\circ} 42^{\prime} 54.30^{\prime \prime}-113^{\circ} 45^{\prime} 06.09 " \mathrm{E}$ ) covers an area of $8175 \mathrm{~km}^{2}$, and is situated in the south of the Wanshan Islands. It is about $29 \mathrm{~km}$ northwest from Macau, $33 \mathrm{~km}$ from Zhuhai City, and 56 km northeast from Hong Kong (Fig. 1).

With an unspoiled natural landscape and an ideal climate, the island is promising for marine ecotourism development. The increasing exploitation of resources for tourism threatens the species that live there. The new species could be potentially seriously threatened and should be regarded as an endangered species.

\section{Material and methods}

\section{Study area}

Dawanshan Island (215 $\left.55^{\prime} 19.69^{\prime \prime}-21^{\circ} 57^{\prime} 21.46 " \mathrm{~N}, 113^{\circ} 42^{\prime} 54.30^{\prime \prime}-113^{\circ} 45^{\prime} 06.09 " \mathrm{E}\right)$ belongs to the Wanshan Islands. It is a small island, $3.35 \mathrm{~km}$ in length, $2.45-3.88 \mathrm{~km}$ in width, with a coastline of $14.42 \mathrm{~km}$, and five bays around the island. There are five peaks, with the highest point of Wanshan Peak in the central part of the north, at $432.5 \mathrm{~m}$ above sea level. Dawanshan Island has loess sandy soil over a rocky base. There are many cliffs on both sides of the south and west, and huge rocks on both sides of the east and north. The island has a subtropical oceanic monsoon climate, which is warm and humid throughout the year, with an average annual temperature of $22-23{ }^{\circ} \mathrm{C}$, an average annual precipitation of $1800-2000 \mathrm{~mm}$ and an average annual relative humidity of $81.0 \%$. Vegetation on Dawanshan Island is of evergreen broad-leaved forest type, 
with a forest coverage rate of about 60\% (Huang and Wang 2000; Liao et al. 2000; He et al. 2004; Huang et al. 2012). The sampling sites of the current study, covering habitats of streams, pools, agricultural waterways, swamps, and brackish water bays are provided in Figure 1.

\section{Collection}

Samples were collected by a hand net with a mesh size of $0.8 \mathrm{~mm}$. All specimens obtained were fixed in $95 \%$ ethanol. The ethanol was changed after 24 hours with fresh $75 \%$ ethanol. The drawings were made with the aid of a drawing tube mounted on an Olympus BX -41 compound microscope.

\section{Genetic analyses}

The forward and reverse primers of the mitochondrial COI gene in this study were: LCO1490 and HCO2198, respectively (Folmer et al. 1994). The PCR reaction was carried out on a Bio-Rad/ $/ \mathrm{T}^{100} \mathrm{TM}$ Thermal Cycler instrument with a system of $50 \mu \mathrm{L}$, of which $25 \mu \mathrm{L}$ of $2 \times$ EasyTaq Mix, $20 \mu \mathrm{L}$ of $\mathrm{ddH}_{2} \mathrm{O}, 2 \mu \mathrm{L}$ of each of the forward and reverse primers, and $1 \mu \mathrm{L}$ of the DNA template. The PCR amplification conditions were: 35 cycles of denaturation at $94^{\circ} \mathrm{C}$ for $30 \mathrm{~s}$, annealing at $46^{\circ} \mathrm{C}$ for $60 \mathrm{~s}$, extension at $72^{\circ} \mathrm{C}$ for $60 \mathrm{~s}$, and a final extension at $72^{\circ} \mathrm{C}$ for $5 \mathrm{~min}$. Five $\mu \mathrm{L}$ of the PCR product was subjected to $1.5 \%$ agarose gel electrophoresis for detection of the amplified product. After successful detection, sequences were obtained by Applied Biosystems 3730 Analyzer (Applied Biosystems, Foster City, CA, USA), after verification with the complementary strand.

A total of 26 nucleotide sequences were analyzed. Selected species for the molecular analyses were species similar to the morphology and the color of the new species and the Caridina species that are known to occur on neighbouring islands. All the sequences were aligned with MAFFT v7.313 software using the auto strategy and normal alignment mode (Katoh and Standley 2013). In order to find the best-fitting model for sequence evolution, ModelFinder (Kalyaanamoorthy et al. 2017) was used. According to Bayes information criterion (ModelFinder default recommendation), the best models for analysis maximum likelihood method (ML) and Bayesian method (BI) are $\mathrm{TIM} 2+\mathrm{F}+\mathrm{I}+\mathrm{G} 4$ and $\mathrm{GTR}+\mathrm{F}+\mathrm{G} 4$, respectively. ML was performed using IQ-TREE 1.6.12 (Nguyen et al. 2015). Bayesian phylogeny was applied using MrBayes v3.2.6 (Ronquist et al. 2012). Markov chain Monte Carlo analysis was performed with two simultaneous runs starting with random tress to approximate the posterior probabilities of trees. Each run consisted of four chains, with default heating parameters. It lasted for $2 \times 10^{6}$ generations for the selected Atyidae and the first $25 \%$ of the samples were discarded. Standard deviation of split frequencies $(<0.01)$ was accounted as a convergence index. Genetic distances were calculated using the Kimura 2-parameter model in MEGA 7.0 based on COI (Kumar et al. 2016). 


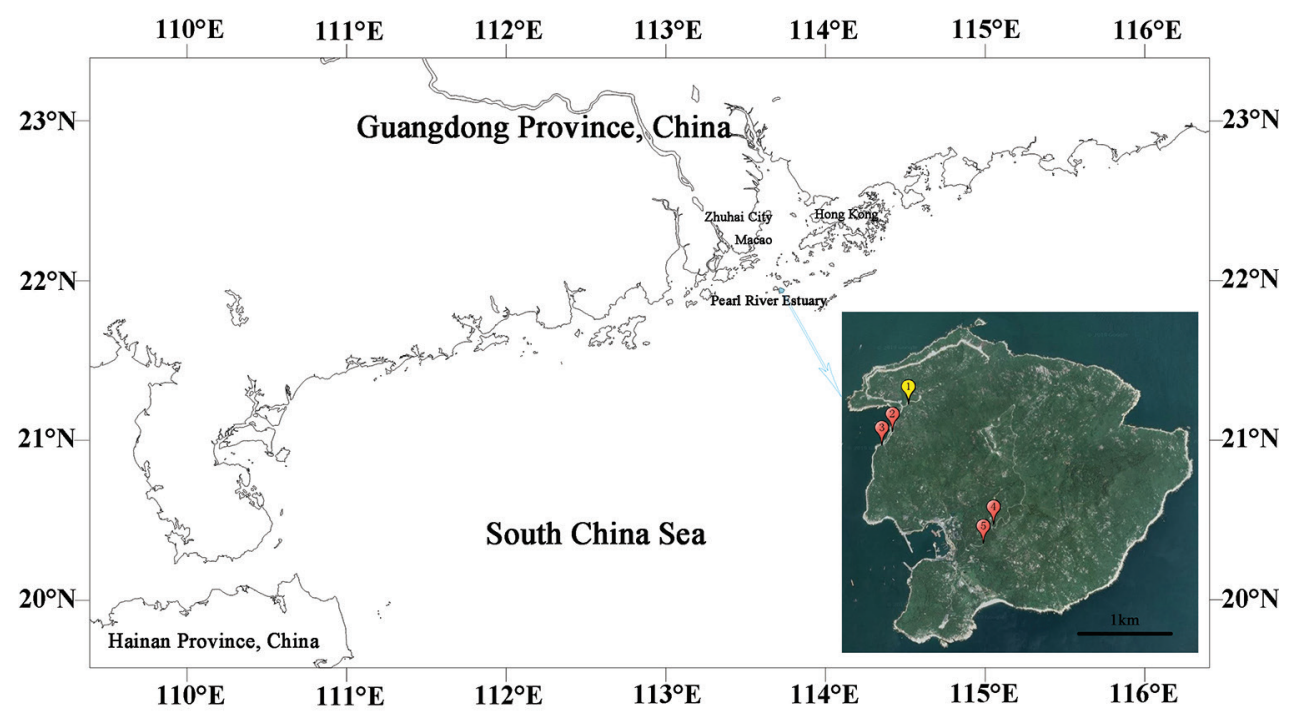

Figure I. The light blue point shows the location of Dawanshan Island. The inset shows the sample locations. The yellow icon (stn 1) shows the collection site of Caridina tetrazona sp. nov., and red icons (stns 2-5) are the collection sites of C. serrata.

Table I. Specimens of the atyids Caridina and Neocaridina used in the molecular analyses (new sequences), listed by localities, geographical coordinates and GenBank accession numbers.

\begin{tabular}{|c|c|c|c|}
\hline Species & Locality & Geographical coordinates & Accession no. \\
\hline \multirow[t]{4}{*}{ C. cantonensis } & Wutong Mountain, Shenzhen & $22^{\circ} 34^{\prime} 49^{\prime \prime} \mathrm{N}, 114^{\circ} 12^{\prime} 44^{\prime \prime} \mathrm{E}$ & MN701589 \\
\hline & Wutong Mountain, Shenzhen & $22^{\circ} 34^{\prime} 49^{\prime \prime N}, 114^{\circ} 12^{\prime} 44^{\prime \prime E}$ & MN701590 \\
\hline & Baiyun Mountain, Guangzhou & $23^{\circ} 10^{\prime} 05^{\prime \prime} \mathrm{N}, 113^{\circ} 17^{\prime} 36^{\prime \prime E}$ & MN701591 \\
\hline & Baiyun Mountain, Guangzhou & $23^{\circ} 10^{\prime} 05^{\prime \prime N}, 113^{\circ} 17^{\prime} 36^{\prime \prime E}$ & MN701592 \\
\hline \multirow[t]{2}{*}{ C. huananensis } & Yingde, Qingyuan & $23^{\circ} 54^{\prime} 17^{\prime \prime N}, 113^{\circ} 15^{\prime} 55^{\prime \prime E}$ & MN701607 \\
\hline & Yingde, Qingyuan & $23^{\circ} 54^{\prime} 17^{\prime \prime} \mathrm{N}, 113^{\circ} 15^{\prime} 55^{\prime \prime} \mathrm{E}$ & MN701608 \\
\hline \multirow[t]{2}{*}{ C. lanceifrons } & Dongfang, Hainan & $18^{\circ} 40^{\prime} 06^{\prime \prime} \mathrm{N}, 109^{\circ} 56^{\prime} 32^{\prime \prime} \mathrm{E}$ & MN701605 \\
\hline & Dongfang, Hainan & $18^{\circ} 40^{\prime} 06^{\prime \prime N}, 109^{\circ} 56^{\prime} 32^{\prime \prime E}$ & MN701606 \\
\hline \multirow[t]{2}{*}{ C. mariae } & Nankun Mountain, Huizhou & $23^{\circ} 39^{\prime} 32^{\prime \prime} \mathrm{N}, 113^{\circ} 54^{\prime} 19^{\prime \prime} \mathrm{E}$ & MN701601 \\
\hline & Nankun Mountain, Huizhou & $23^{\circ} 39^{\prime} 32^{\prime \prime} \mathrm{N}, 113^{\circ} 54^{\prime} 19^{\prime \prime} \mathrm{E}$ & MN701602 \\
\hline \multirow[t]{4}{*}{ C. serrata } & Dawanshan Island, Zhuhai & $21^{\circ} 33^{\prime} 41^{\prime \prime N}, 113^{\circ} 25^{\prime} 59^{\prime \prime E}$ & MN701595 \\
\hline & Dawanshan Island, Zhuhai & $21^{\circ} 33^{\prime} 41^{\prime \prime N}, 113^{\circ} 25^{\prime} 59^{\prime \prime E}$ & MN701596 \\
\hline & Dong'ao Island, Zhuhai & $22^{\circ} 00^{\prime} 17^{\prime \prime} \mathrm{N}, 113^{\circ} 25^{\prime} 27^{\prime \prime} \mathrm{E}$ & MN701599 \\
\hline & Dong'ao Island, Zhuhai & $22^{\circ} 00^{\prime} 17^{\prime \prime N}, 113^{\circ} 25^{\prime} 27^{\prime \prime E}$ & MN701600 \\
\hline \multirow[t]{2}{*}{ C. tetrazona sp. nov. } & Dawanshan Island, Zhuhai & $21^{\circ} 33^{\prime} 57^{\prime \prime} \mathrm{N}, 113^{\circ} 25^{\prime} 48^{\prime \prime} \mathrm{E}$ & MN701593 \\
\hline & Dawanshan Island, Zhuhai & $21^{\circ} 33^{\prime} 57^{\prime \prime N}, 113^{\circ} 25^{\prime} 48^{\prime \prime E}$ & MN701594 \\
\hline \multirow[t]{2}{*}{ C. zhujiangensis } & Dong'ao Island, Zhuhai & $22^{\circ} 00^{\prime} 38^{\prime \prime N}, 113^{\circ} 25^{\prime} 13^{\prime \prime} \mathrm{E}$ & MN701603 \\
\hline & Dong'ao Island, Foshan & $22^{\circ} 00^{\prime} 38^{\prime \prime N} \mathrm{~N}, 113^{\circ} 25^{\prime} 13^{\prime \prime} \mathrm{E}$ & MN701604 \\
\hline \multirow[t]{2}{*}{ N. palmata } & Yangshan, Qingyuan & $24^{\circ} 25^{\prime} 28^{\prime \prime N}, 112^{\circ} 36^{\prime} 28^{\prime \prime} \mathrm{E}$ & MN701609 \\
\hline & Yangshan, Qingyuan & $24^{\circ} 25^{\prime} 28^{\prime \prime N}, 112^{\circ} 36^{\prime} 28^{\prime \prime} \mathrm{E}$ & MN701610 \\
\hline \multirow[t]{2}{*}{ N. hofendopoda } & Sanxia, Yichang & $30^{\circ} 49^{\prime} 32^{\prime \prime} \mathrm{N}, 111^{\circ} 00^{\prime} 59^{\prime \prime E}$ & MN701611 \\
\hline & Sanxia, Yichang & $30^{\circ} 49^{\prime} 32^{\prime \prime N}, 111^{\circ} 00^{\prime} 59^{\prime \prime} \mathrm{E}$ & MN701612 \\
\hline
\end{tabular}




\section{Abbreviations}

The following abbreviations are used throughout the text: al: altitude; cl: carapace length (measured from the postorbital margin to the posterior margin of the carapace); coll: sample collectors; rl: rostral length (measured from the rostral tip to the postorbital margin); stn: sampling station; tl: total length (measured from the rostral tip to the posterior margin of the telson). All measurements are in millimeters.

Specimens were deposited in the Department of Animal Science, School of Life Science and Engineering, Foshan University (FU).

\section{Systematic accounts}

Family Atyidae De Haan, 1849

Subfamily Atyinae De Haan, 1849

Genus Caridina H. Milne Edwards, 1837

\section{Caridina serrata Stimpson, 1860}

Figs 2B, C, 3B, C

Caridina serrata Stimpson, 1860: 29 [type locality: Hong Kong, China].

Caridina serrata-Ortmann 1894: 406; Bouvier 1905: 76; 1925: 258, fig. 593; Kemp 1918: 289, fig. 12; Cai and Ng 1999: 1605, figs 2, 3; Liang 2004: 173, fig. 83; Chen et al. 2018: 315, figs 2, 3 .

Material examined. 13 females, cl 3.5-6.8 mm, 2 ovigerous cl 3.7-5.6 mm, 5 males cl 3.0-5.8 mm, a small pool (21 ${ }^{\circ} 56^{\prime} 48.6^{\prime \prime} \mathrm{N}, 113^{\circ} 42^{\prime} 55.5^{\prime \prime} \mathrm{E}$, al. $5.4 \mathrm{~m}$, stn 2$)$, 27 June 2017, coll. Z. L. Guo, W. J. Chen; 17 females, cl 3.4-6.6 mm, 2 ovigerous females, cl 4.1-5.6 mm, 15 males, cl 2.9-5.5 mm, a small stream $\left(21^{\circ} 56^{\prime} 43.6^{\prime \prime} \mathrm{N}\right.$, $113^{\circ} 42^{\prime} 51.4^{\prime \prime E}$, al. $27.2 \mathrm{~m}$, stn 3), 27 June 2017, coll. Z. L. Guo, W. J. Chen; 5 females, cl 3.1-6.9 mm, 3 ovigerous, cl 3.5-5.8 mm, 3 males, cl $3.0-5.2 \mathrm{~mm}$, a small

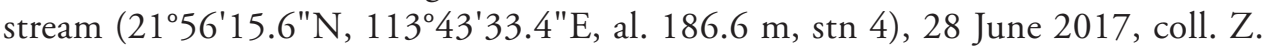
L. Guo, W. J. Chen; 7 females, cl 3.4-6.9 mm, 4 males, cl 3.5-5.7 mm, a small stream (21 ${ }^{\circ} 56^{\prime} 02.8^{\prime \prime N}, 113^{\circ} 43^{\prime} 29.0^{\prime \prime E}$, al. $122.8 \mathrm{~m}$, stn 5), 28 June 2017, coll. Z. L. Guo, W. J. Chen.

Remarks. The present specimens are in agreement with the description and illustrations of Cai and $\mathrm{Ng}$ (1999) and Liang (2004). Caridina serrata is highly adaptable and prolific, distributed everywhere on the Wanshan Islands, such as Dong'ao Island, Guishan Island, and Wailingding Island (Chen et al. 2018). A close biogeographical connection of the atyid faunas among the Wanshan Islands is evident. This species is also distributed in Hong Kong (Cai and Ng 1999), Chaqiao, and Zhongshan City (Liang 2004). 


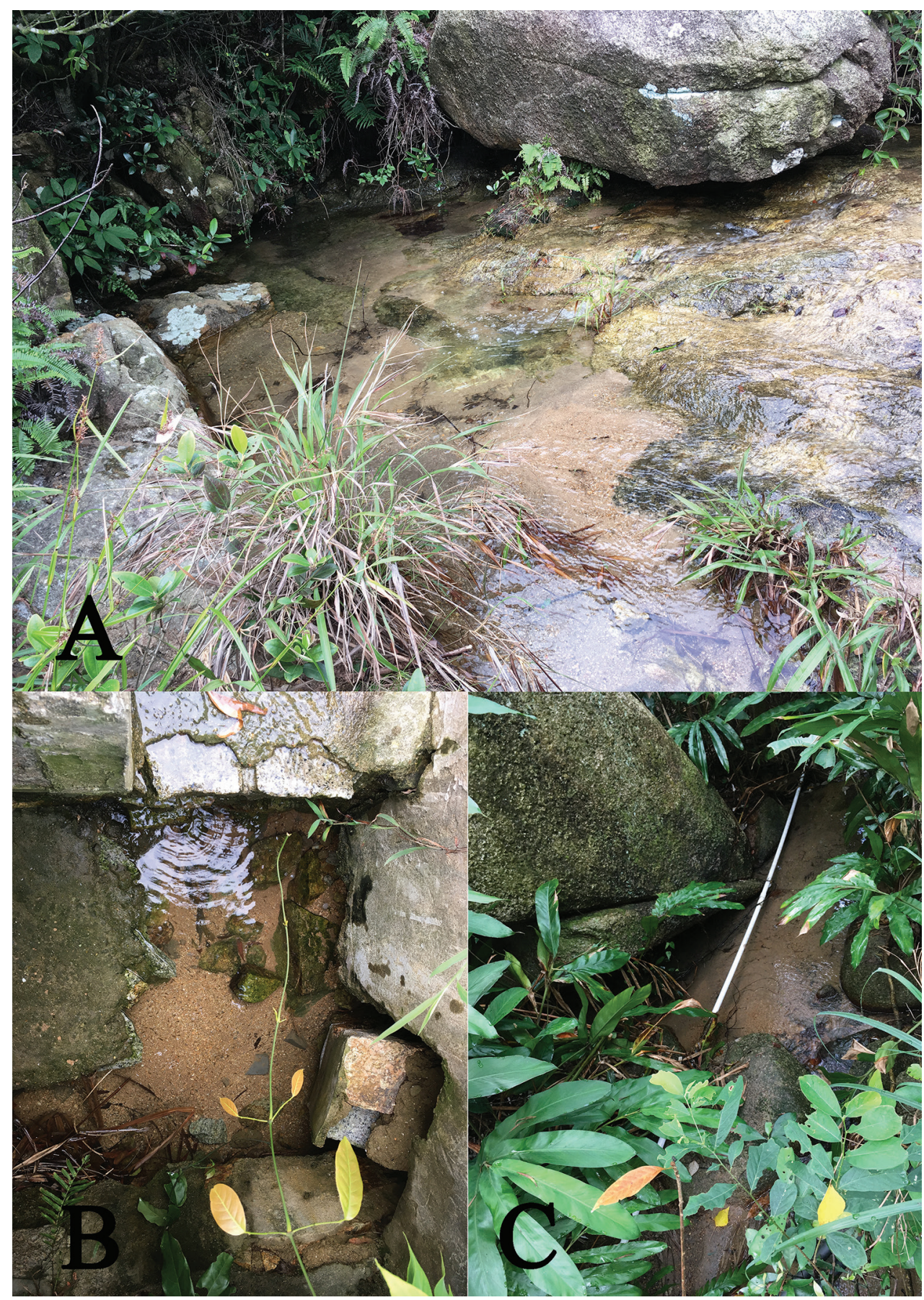

Figure 2. Habitats of the two shrimp species in this study. A Habitat of Caridina tetrazona sp. nov. B, $\mathbf{C}$ habitat of $C$. serrata. 
Ecological notes. Caridina serrata is commonly found in pools, streams, and artificial ditches on the island. Sometimes, the stream connects with the sea. Sediment at the site comprised sand, pebbles and gravel patches between large boulders. Hill streams are within secondary forests and are covered with aquatic plant (Fig. 2B, C). The water parameters of the streams at the time of collection were: temperature 24-26 ${ }^{\circ} \mathrm{C}$, pH 5.8-6.5, dissolved ammonia nitrogen $0.20-0.22 \mathrm{mgl}^{-1}$, and dissolved oxygen 7.8-8.6 mgl-1; the water was clear and flowing. Caridina serrata is associated with dead leaves and aquatic plants, but also lives under pebbles and stones. The female carries fewer but large eggs $(0.5-0.7 \times 0.9-1.0 \mathrm{~mm})$. The larvae go through direct development and hatch into benthic hatchlings that resemble miniature adults.

Coloration. The live shrimp show light-red coloration and are translucent (Fig. 3B, C).

Distribution. Southern China (Hong Kong, Zhuhai City and Zhongshan City of Guangdong Province).

\section{Caridina tetrazona sp. nov.}

http://zoobank.org/F3E1596D-A5CE-47B0-8926-19E95DAAC97A

Figs $2 \mathrm{~A}, 3 \mathrm{~A}, 4,5$

Material examined. Holotype: male (FU, 2017-06-27-01), cl $3.9 \mathrm{~mm}$, tl $14.4 \mathrm{~mm}$, rl $1.3 \mathrm{~mm}$, a stream near Longtangzui Dawanshan Island, Zhuhai City, Guangdong, China $\left(21^{\circ} 56^{\prime} 59.2^{\prime \prime N}, 113^{\circ} 43^{\prime} 00^{\prime E}\right.$, al. 8 m, stn 1), 9 June 2017. Paratypes: male (FU, 2017-06-27-02), cl 4.3 mm, 4 males (FU, 2017-06-27-03), cl 3.8-4.3 mm, 33 females, 4 ovigerous (FU, 2017-06-27-04), cl 3.8-5.4 mm, same collection data as for holotype, coll. Z. L. Guo, W. J. Chen.

Comparative material. Caridina serrata Stimpson, 1860 (see material under $\mathrm{Ca}$ ridina serrata). Caridina cantonensis Yu, 1938; 8 males, cl 3.5-6.3 mm, 5 females, 2 ovigerous, cl 4.1-6.3 mm, a stream at Mangzixia, Yingde, Qingyuan City, Guangdong, China $\left(24^{\circ} 3^{\prime} 20^{\prime \prime N}, 113^{\circ} 19^{\prime} 6^{\prime \prime E}\right.$, al. 20 m), 4 June 2018, coll. Z. L. GUO, W. J. Chen, X. Z. Zheng.

Diagnosis. Rostrum short, straight or slightly sloping downwards, nearly reaching to or slightly reaching beyond end of $1^{\text {st }}$ segment of antennular peduncle, rostral formula 3-8 (usually $5-7$ ) $+4-6 / 1-2.1^{\text {st }}$ pereiopod carpus $0.63-0.70 \times$ as long as chela, 1.6-1.7 $\times$ as long as high; chela $1.8-2.0 \times$ as long as broad; fingers $0.92-1.1 \times$ as long as palm. $2^{\text {nd }}$ pereiopod carpus $1.1-1.3 \times$ as long as chela, $4.9-5.3 \times$ as long as high; chela $2.7-2.9 \times$ as long as broad; fingers $1.7-1.8 \times$ as long as palm. $3^{\text {rd }}$ pereiopod propodus 3.9-4.5x as long as dactylus, with $8-11$ thin spines on the posterior and lateral margins. $5^{\text {th }}$ pereiopod propodus $4.9-5.1 \times$ as long as dactylus, with 8-11 thin spines on the posterior and lateral margins, dactylus terminating in one claw, with $27-31$ spinules on flexor margin. Endopod of male $1^{\text {st }}$ pleopod extending to $0.56 \times$ exopod length, wider proximally, subrectangular, 2.5-2.6 $\times$ as long as wide, appendix interna well developed, arising from distal $1 / 3$ of endopod, reaching beyond end of 


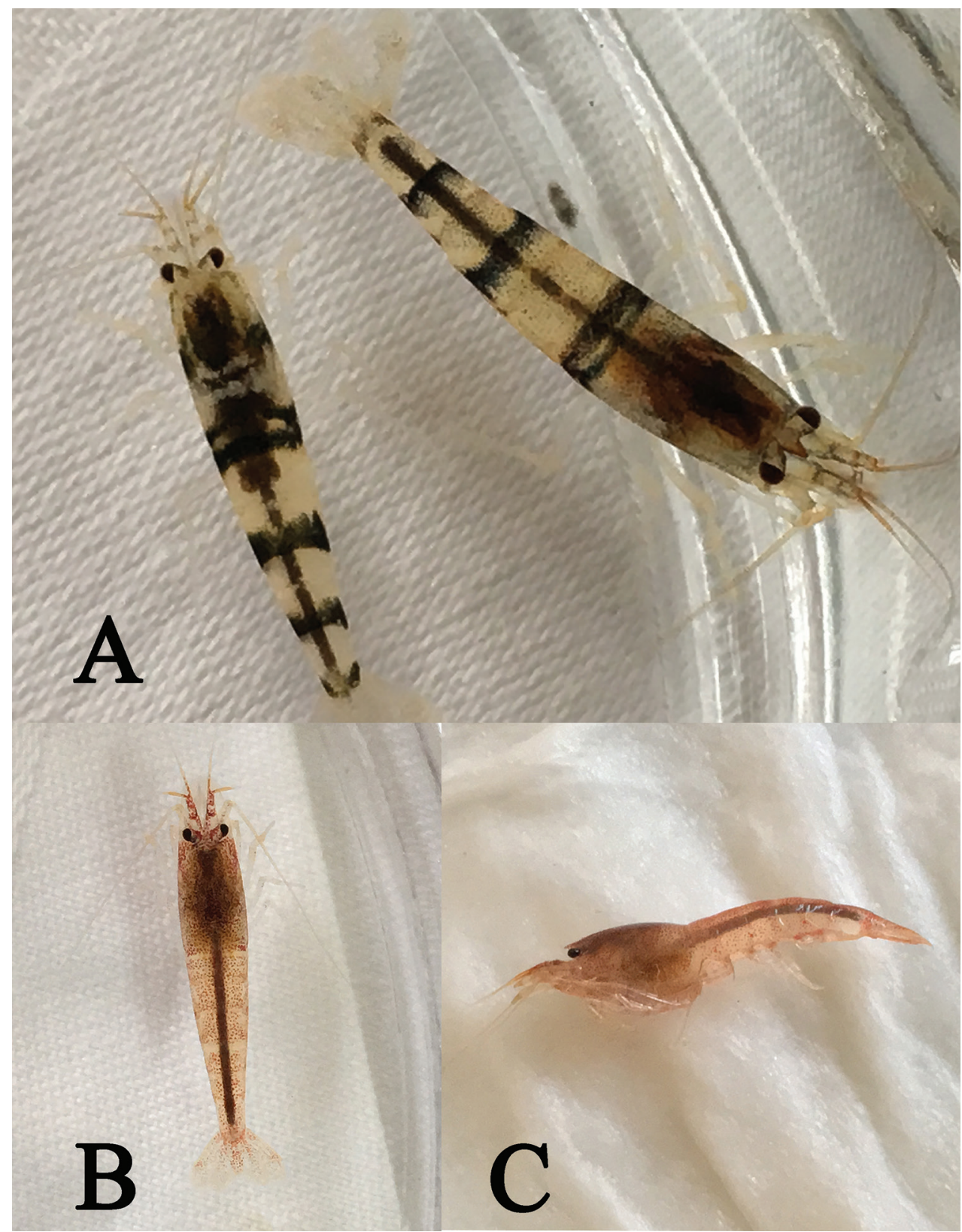

Figure 3. Photos of live specimens of the two species of Caridina from Dawanshan Island. A Caridina tetrazona sp. nov. B dorsal view of $C$. serrata $\mathbf{C}$ lateral view of $C$. serrata.

endopod. Appendix masculina of male $2^{\text {nd }}$ pleopod rod-shaped, reaching to 0.7 length of endopod, appendix interna reaching to 0.7 length of appendix masculina. Uropodal diaeresis with 18-20 movable spinules. Eggs $0.51-0.65 \times 0.84-0.97 \mathrm{~mm}$ in diameter. 
Description. Body: small, slender and sub-cylindrical, males up to $14.8 \mathrm{~mm} \mathrm{tl}$, females up to $20.4 \mathrm{~mm}$ tl.

Rostrum (Fig. 4A, B): Short, only $0.15-0.32$ of $\mathrm{cl}$, straight or slightly sloping downwards; reaching end of basal segment of antennular peduncle, or to just beyond it; armed dorsally with 7-14 teeth, including 3-8 (usually 5-7) on carapace posterior to orbital margin, ventrally with 1-2 teeth; lateral carina dividing rostrum into two unequal parts, continuing posteriorly to orbital margin.

Eyes (Fig. 4A, B): Well developed on short ocular peduncle, cornea globular.

Carapace (Fig. 4A, B): Smooth, glabrous; antennal spine acute, fused with inferior orbital angle; pterygostomian margin broadly rounded or slightly produced forward; no pterygostomian.

Antennule (Fig. 4A-C): Peduncle reaching slightly short of scaphocerite; stylocerite long, reaching $0.3 \times$ of $2^{\text {nd }}$ segment; anterolateral angle reaching $0.2 \times$ of $2^{\text {nd }}$ segment; length of basal segment as long as sum of length of $2^{\text {nd }}$ and $3^{\text {rd }}$ segments, $2^{\text {nd }}$ segment $0.46-0.51 \times$ of basal segment, $1.1-1.3 \times$ of $3^{\text {rd }}$ segment; all segments with sub-marginal plumose setae.

Antenna (Fig. 4D): Peduncle about $0.54 \times$ of scaphocerite; scaphocerite about $3.6 \times$ as long as wide, outer margin straight, ending in strong sub-apical spine, inner and anterior margins with long plumose setae.

Mandible (Fig. 4E): Without palp; left incisor process with 4 sharp teeth; medially 2 groups of setae; molar process ridged.

Maxillula (Fig. 4F): Lower lacinia broadly rounded, with several rows of plumose setae; upper lacinia elongate, medial edge straight, with 29 strong spinules and simple setae; palp simple, slightly expanding distally, with 4 long simple setae.

Maxilla (Fig. 4G): Scaphognathite tapering posteriorly, distally with regular row of long plumose setae and short marginal plumose setae continuing down proximal triangular process, furnished with numerous long plumose setae; upper and middle endite with marginal simple, denticulate and sub-marginal simple setae, distally with plumose setae; lower endite with long simple marginal setae; palp distinctly shorter than cleft of upper endite, wider proximally than distally.

First maxilliped (Fig. 4H): Palp broadly triangular ending in fringe-like tip and with terminal plumose setae; caridean lobe broad, with marginal plumose setae; exopodal flagellum well developed, with distally marginal plumose setae; ultimate and penultimate segments of endopod indistinctly divided; medial and distal margins of ultimate segment with marginal and sub-marginal rows of simple, denticulate and plumose setae; penultimate segments with marginal long plumose setae.

Second maxilliped (Fig. 4I): Ultimate and penultimate segments of endopod indistinctly divided, reflexed against basal segment; inner margin of ultimate, penultimate and basal segments with long setae of various types; exopod flagellum long, slender with marginal plumose setae distally.

Branchial formula typical for genus. Epipod on first four pereiopods.

Third maxilliped (Fig. 5A): Reaches to end of $2^{\text {nd }}$ antennular peduncle segment, endopod three-segmented, penultimate segment as long as basal segment; distal seg- 


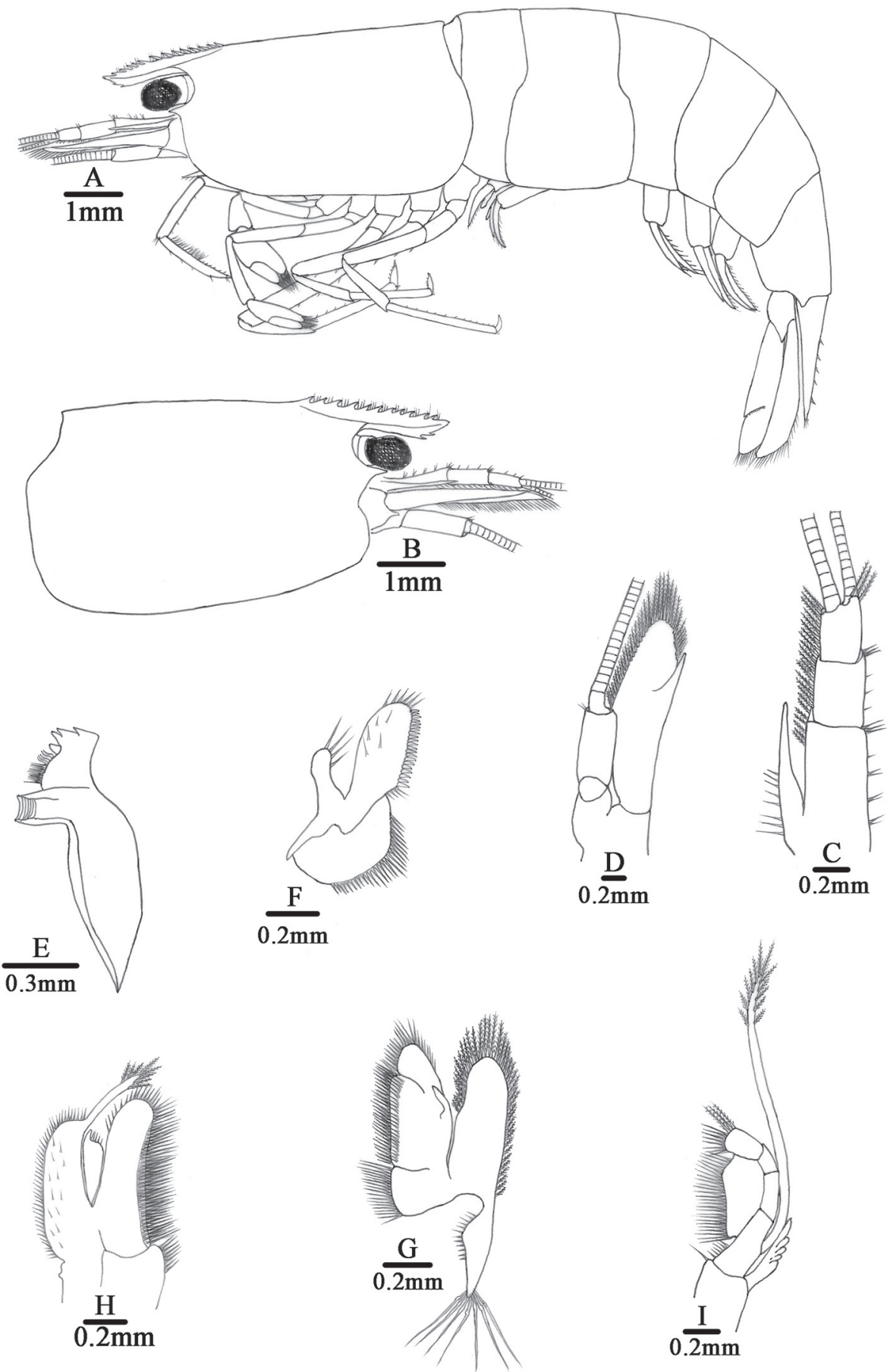

Figure 4. Caridina tetrazona sp. nov. A Entire animal, lateral view, holotype (FU, 2017-06-27-01) B-I paratype (FU, 2017-06-27-02) B carapace and cephalic appendages, lateral view $\mathbf{C}$ antennule $\mathbf{D}$ antenna $\mathbf{E}$ mandible $\mathbf{F}$ maxillula $\mathbf{G}$ maxilla $\mathbf{H}$ first maxilliped $\mathbf{I}$ second maxilliped. 
ment $0.87-0.90 \times$ as long as penultimate segment, ending in a large claw-like spine surrounded by simple setae, preceded by about 5-8 spines on distal third of posterior margin, proximally a clump of long and short simple, serrate setae; exopod reaches to end of basal segment of endopod, distal margin with long plumose setae.

First pereiopod (Fig. 5B): Reaches end of eyes; chela 1.8-2.2 $\times$ as long as wide; $1.4-1.6 \times$ as long as carpus; movable finger $2.8-3.2 \times$ as long as wide, $0.92-1.1 \times$ as long as palm, setal brushes well developed; carpus excavated anterior-dorsally, 1.5$1.8 \times$ as long as high, $0.90-1.0 \times$ as long as merus.

Second pereiopod (Fig. 5C): Reaches about end of $3^{\text {rd }}$ antennular peduncle segment, more slender and longer than first pereiopod; chela 2.6-3.2 $\times$ as long as wide; 0.78-0.87 $\times$ as long as carpus; movable finger 4.0-4.6 $\times$ as long as wide and $1.5-1.7 \times$ as long as palm, setal brushes well developed; carpus 4.9-5.9 $\times$ as long as high, slightly excavated anterior, as long as merus.

Third pereiopod (Fig. 5D): Reaches beyond end of scaphocerite; dactylus 2.9$3.5 \times$ as long as wide, ending in prominent claw-like spine surrounded by simple setae, flexor margin bearing 4-5 spines; propodus 4.5-4.9 $\times$ as long as dactylus, bearing 8-12 spinules on posterior and lateral margin, 8.4-9.7 $\times$ as long as wide; carpus $0.67-0.82 \times$ as long as propodus; merus $1.7-2.0 \times$ as long as carpus, with about 3-4 strong spines on the posterior margin.

Fourth pereiopod: Reaches middle of $2^{\text {nd }}$ segment of antennular peduncle; dactylus 3.0-4.2 $\times$ as long as wide, ending in prominent claw-like spine surrounded by simple setae, flexor margin bearing 4-6 spines; propodus 4.2-5.1 $\times$ as long as dactylus, bearing 9-13 spinules on posterior and lateral margin, 8.5-10.5 $\times$ as long as wide; carpus $0.66-0.81 \times$ as long as propodus; merus $1.6-1.8 \times$ as long as carpus, with about 3-4 strong spines on the posterior margin.

Fifth pereiopod (Fig. 5E): Reaches middle of $1^{\text {st }}$ segment of antennular peduncle; dactylus 2.8-3.6 $\times$ as long as wide, ending in prominent claw-like spine surrounded by simple setae, flexor margin bearing with a row of 27-31 comb-like spinules; propodus 4.7-5.1 $\times$ as long as dactylus, bearing 8-11 spinules on posterior and lateral margin, 8.9-11.9 $\times$ as long as wide; carpus $0.52-0.62 \times$ as long as propodus; merus $1.3-1.5 \times$ as long as carpus, with about 3-4 strong spines on the posterior margin.

First pleopod (Fig. 5F): Endopod of male subrectangular, wider proximally, $0.56 \times$ as long as exopod, 2.5-2.6 $\times$ as long as proximal wide, ending broadly rounded; inner margin slightly concave, bearing short spine-like setae, outer margin slightly convex, bearing long spine-like setae, distinctly longer and stout on distal $1 / 3$, distal end tip bearing nearly equal length shorter spine-like setae; appendix interna well developed, arising from distal 1/3 of endopod, reaching beyond end of endopod, distally with numerous cincinulli.

Second pleopod (Fig. 5G): Appendix masculina rod-shaped, reaching about $0.7 \times$ length of exopod, inner margin and tip bearing numerous spine setae; appendix interna slender, reaching about $0.73 \times$ length of appendix masculina, distally with many cincinulli.

Telson (Fig. 5H): $0.56-0.75 \times$ as long as $\mathrm{cl}$, tapering posterior, dorsal surface with 6 pairs of stout movable spine-like setae including the pair at poster lateral angles; 

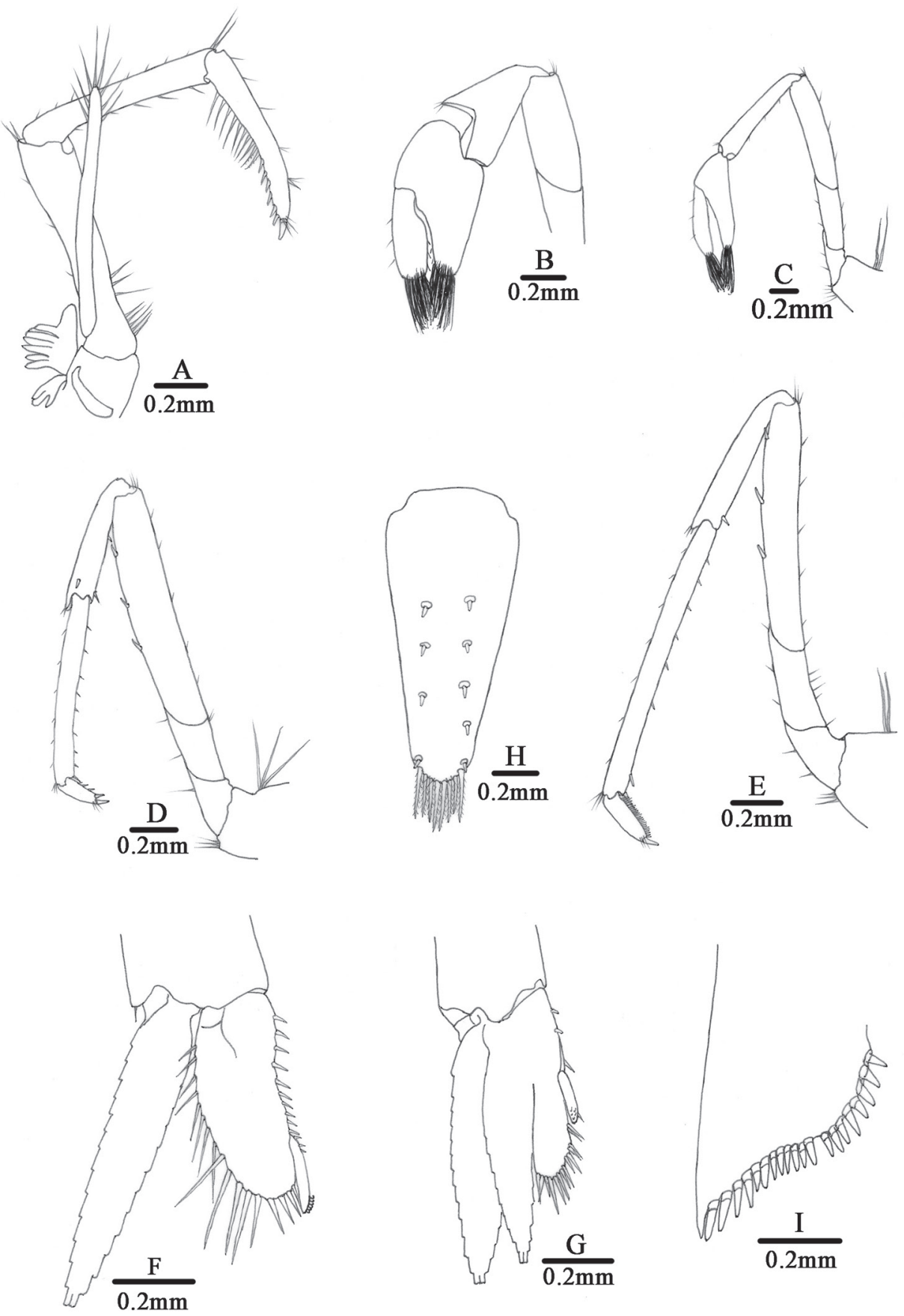

Figure 5. Caridina tetrazona sp. nov. paratype (FU, 2017-06-27-02). A Third maxilliped B first pereiopod $\mathbf{C}$ second pereiopod $\mathbf{D}$ third pereiopod $\mathbf{E}$ fifth pereiopod $\mathbf{F}$ first pleopod $\mathbf{G}$ second pleopod $\mathbf{H}$ telson I diaeresis of uropodal exopod. 
posterior margin with 4-5 pairs of intermediate plumose setae, the outer one usually strongest and longest, no median projection on posterior margin. Exopodite of uropod bearing a series of 18-20 movable spinules on the diaeresis.

Eggs $0.51-0.65 \times 0.84-0.97 \mathrm{~mm}$ in diameter.

Coloration: Body semi-translucent, four dark blue bands transverse on the tergum of the $1^{\text {st }}, 3^{\text {rd }}, 5^{\text {th }}$, and $6^{\text {th }}$ abdominal segments, appendages mostly translucent (Fig. 3A).

Etymology. Caridina tetrazona is a combination of two Latin words, tetra, four, and zona, band, alluding to its four-banded color pattern.

Remarks. Caridina tetrazona sp. nov. is most similar to C. serrata Stimpson, 1860 (which also occurs on the same island) in the short rostrum, the shape of the endopod of the male first pleopod, and the similar-sized eggs. It can be easily distinguished from C. serrata by the length of the basal segment of the antennular peduncle which is as long as the combined length of $2^{\text {nd }}$ and $3^{\text {rd }}$ segments (versus length of basal segment distinctly longer than the combined length of $2^{\text {nd }}$ and $3^{\text {rd }}$ segments in $C$. serrata); length of penultimate segment of $3^{\text {rd }}$ maxilliped as long as basal segment; the distal segment is distinctly shorter than the penultimate segment (versus penultimate segment distinct shorter than basal segment and distal segment as long as penultimate segment in $C$. serrata); the absence of a projection on the posterior margin of telson (versus with a projection in C. serrata), and the slender scaphocerite (3.6-3.7 times as long as wide versus 3.0-3.2 times in $C$. serrata). In addition, the four dark blue bands on the body of live shrimps allow an easy identification in the field. Caridina tetrazona sp. nov. also shows close similarity with $C$. cantonensis $\mathrm{Yu}, 1938$ regarding the ratios of various segments of the $1^{\text {st }}$ and $2^{\text {nd }}$ pereiopods. Beside its peculiar coloration, C. tetrazona sp. nov. differs from $C$. cantonensis in the short rostrum, which only reaches the end of $1^{\text {st }}$ segment of the antennular peduncle (versus distinctly reaches beyond the end of the $2^{\text {nd }}$ segment in $C$. cantonensis); the endopod of the male first pleopod slender (2.6-2.7 times as long as wide versus 2.1-2.4 times in $C$. cantonensis) and distal part not dilated (versus distally distinctively dilated in C. cantonensis); palp of $1^{\text {st }}$ maxilliped ending in a finger-like tip (versus broadly rounded in $C$. cantonensis); and absence of a projection on the posterior telsonic margin (versus with a projection in $C$. cantonensis). Caridina tetrazona sp. nov. closely resembles C. trifasciata Yam \& Cai, 2003, in having similar dark blue bands on their abdomen, and in having the shape of the endopod of the male $1^{\text {st }}$ pleopod and appendix masculina of the male $2^{\text {nd }}$ pleopod similar. Caridina tetrazona sp. nov. differs from $C$. trifasciata in its proportionately shorter rostrum (only reaches the end of the $1^{\text {st }}$ segment of the antennular peduncle versus reaches beyond the end of the $2^{\text {nd }}$ segment in $C$. trifasciata); palp of the $1^{\text {st }}$ maxilliped ending in a finger-like tip (versus broadly rounded in C. trifasciata); and the slender scaphocerite (3.6-3.7 times as long as wide versus 2.8 times in $C$. trifasciata).

Ecological notes. The type specimens were collected from a small stream at an elevation of $8 \mathrm{~m}$, stn 1, near Longtangzui, Dawanshan Island, Zhuhai City, Guangdong, China $\left(21^{\circ} 56^{\prime} 59.2^{\prime \prime} \mathrm{N}, 113^{\circ} 43^{\prime} 00^{\prime \prime E}\right.$ ) (Fig. 1). The stream is 2-3 $\mathrm{m}$ in width and $0.3-0.5 \mathrm{~m}$ in depth. The stream bed consists of rocks interspersed with gravel and 
sands patches. The bank was covered with aquatic vegetation. The shrimps live among rocks and marginal vegetation. The stream water was fast flowing and the temperature was $26^{\circ} \mathrm{C}$, pH was 6.4 , and dissolved oxygen concentrations was $7.8 \mathrm{mg} / 1$.

Distribution. only known from Guangdong Province, southern China.

\section{Molecular phylogenetic results}

The primers used in this study are located at the 5' end of the COI gene, and the new sequencing results are corrected for 624 bp for subsequent analysis. As can be seen from Table 2, pairwise genetic distances between Caridina tetrazona sp. nov. and $C$. serrata and $C$. cantonensis are 0.067 and 0.128 , respectively. The topology of the Bayesian (BI) trees and the ML tree are basically similar. Phylogenetic trees revealed the relationship between Caridina tetrazona sp. nov. and nine other species of Atyidae, with the posterior probability and bootstrap values from the BI and ML analyses shown in Figures 6 and 7.

\section{Discussion}

The faunistic and ecological results of the present survey illustrate that the freshwater atyid shrimps are not very diverse along the habitats of the coastline of Dawansha Island; only two species of Caridina occur on this island. Caridina tetrazona is a new species, while Caridina serrata Stimpson, 1860 is known from a wide area and can be commonly found in streams from this island. In addition, it also occurs on neighboring islands, i.e., Hong Kong, Dong'ao Island, Wailingding Island, and Guishan Island (Cai and Ng 1999; Chen et al. 2018). The Wanshan Islands together have the same geological origin, and therefore a close biogeographical connection of their atyid faunas is evident.

Table 2. Pairwise genetic distance among eight Caridina species (Atyidae) based on the COI gene. The range of genetic distances between different species is in parentheses.

\begin{tabular}{|c|c|c|c|c|c|c|c|}
\hline Species & 1 & 2 & 3 & 4 & 5 & 6 & 7 \\
\hline \multicolumn{8}{|l|}{ 1. C. cantonensis } \\
\hline 2. C. huananensis & $\begin{array}{c}0.189 \\
(0.171-0.207)\end{array}$ & & & & & & \\
\hline 3. C. lanceifrons & $\begin{array}{c}0.234 \\
(0.221-0.246)\end{array}$ & $\begin{array}{c}0.246 \\
(0.245-0.246)\end{array}$ & & & & & \\
\hline 4. C. mariae & $\begin{array}{c}0.110 \\
(0.100-0.119)\end{array}$ & $\begin{array}{c}0.216 \\
(0.215-0.216)\end{array}$ & $\begin{array}{c}0.277 \\
(0.277-0.277)\end{array}$ & & & & \\
\hline 5. C. serrata & $\begin{array}{c}0.149 \\
(0.139-0.159)\end{array}$ & $\begin{array}{c}0.240 \\
(0.224-0.255)\end{array}$ & $\begin{array}{c}0.260 \\
(0.252-0.268)\end{array}$ & $\begin{array}{c}0.144 \\
(0.137-0.150)\end{array}$ & & & \\
\hline $\begin{array}{l}\text { 6. C. tetrazona } \\
\text { sp. nov. }\end{array}$ & $\begin{array}{c}0.128 \\
(0.118-0.138)\end{array}$ & $\begin{array}{c}0.203 \\
(0.199-0.206)\end{array}$ & $\begin{array}{c}0.227 \\
(0.227-0.227)\end{array}$ & $\begin{array}{c}0.137 \\
(0.137-0.137)\end{array}$ & $\begin{array}{c}0.067 \\
(0.033-0.101)\end{array}$ & & \\
\hline 7. C. trifasciata & $\begin{array}{c}0.112 \\
(0.105-0.118)\end{array}$ & $\begin{array}{c}0.214 \\
(0.206-0.221)\end{array}$ & $\begin{array}{c}0.256 \\
(0.252-0.260)\end{array}$ & $\begin{array}{c}0.147 \\
(0.144-0.150)\end{array}$ & $\begin{array}{c}0.117 \\
(0.100-0.134)\end{array}$ & $\begin{array}{c}0.091 \\
(0.088-0.094)\end{array}$ & \\
\hline 8. C. zhujiangensis & $\begin{array}{c}0.237 \\
(0.229-0.244)\end{array}$ & $\begin{array}{c}0.325 \\
(0.321-0.329)\end{array}$ & $\begin{array}{c}0.265 \\
(0.265-0.265)\end{array}$ & $\begin{array}{c}0.281 \\
(0.281-0.281)\end{array}$ & $\begin{array}{c}0.291 \\
(0.279-0.303)\end{array}$ & $\begin{array}{c}0.263 \\
(0.263-0.263)\end{array}$ & $\begin{array}{c}0.241 \\
(0.237-0.245)\end{array}$ \\
\hline
\end{tabular}




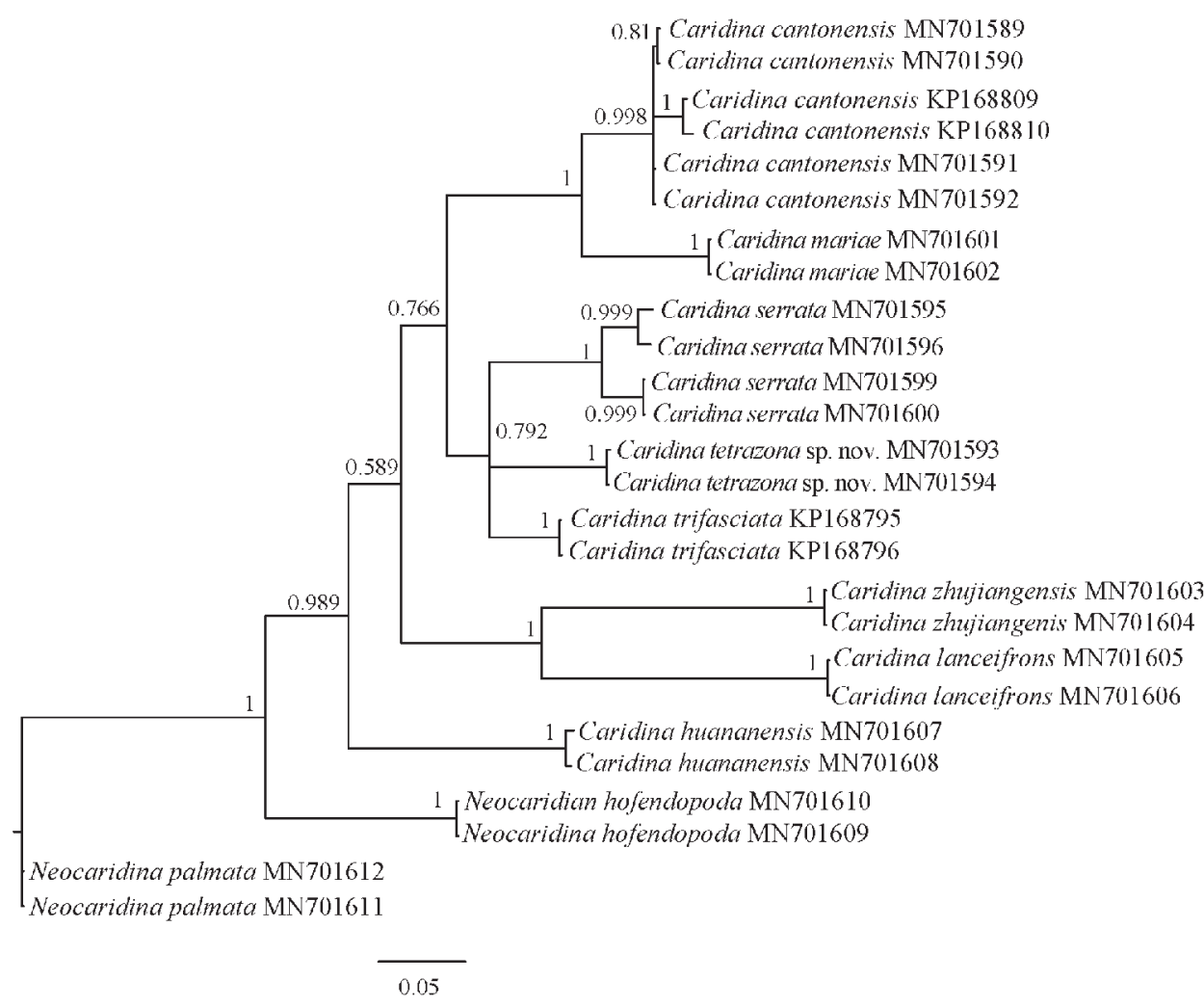

Figure 6. Bayesian inference tree of species of Caridina and outgroups (Neocaridina) based on COI gene. Support values at the nodes represent posterior probability.

According to the COI sequence, the range of interspecific genetic divergence (K2P) between Caridina tetrazona sp. nov. and the other seven species of Caridina was $6.7-32.5 \%$. This result is in accordance with the minimum interspecific genetic distance of $2 \%$ recommended by Hebert et al. (2003). The new species is most similar in morphology to C. serrata and C. cantonensis. According to molecular analyses, the distance between the new species and these two is 0.067 and 0.128 , respectively. In the phylogenetic tree, the new species (C. tetrazona sp. nov.) can also be separated from $C$. cantonensis and $C$. serrata. Therefore, molecular analyses and morphological analysis are congruent, and together provide sufficient evidence to suggest that the rice shrimp in this study is a new taxon.

As these isolated and vicariant atyid shrimps occur in tightly constrained coastal locations, they may be particularly vulnerable to anthropogenic changes. The island has high potential for ecotourism due to its unspoilt natural landscape and ideal climate. The increase in tourism poses a threat to the survival of this species. Moreover, Caridina tetrazona sp. nov. displays a striking coloration pattern, which will certainly receive particular attention among aquarists, so the possible threat by over-harvesting is also present. A program should be developed to guide and control 


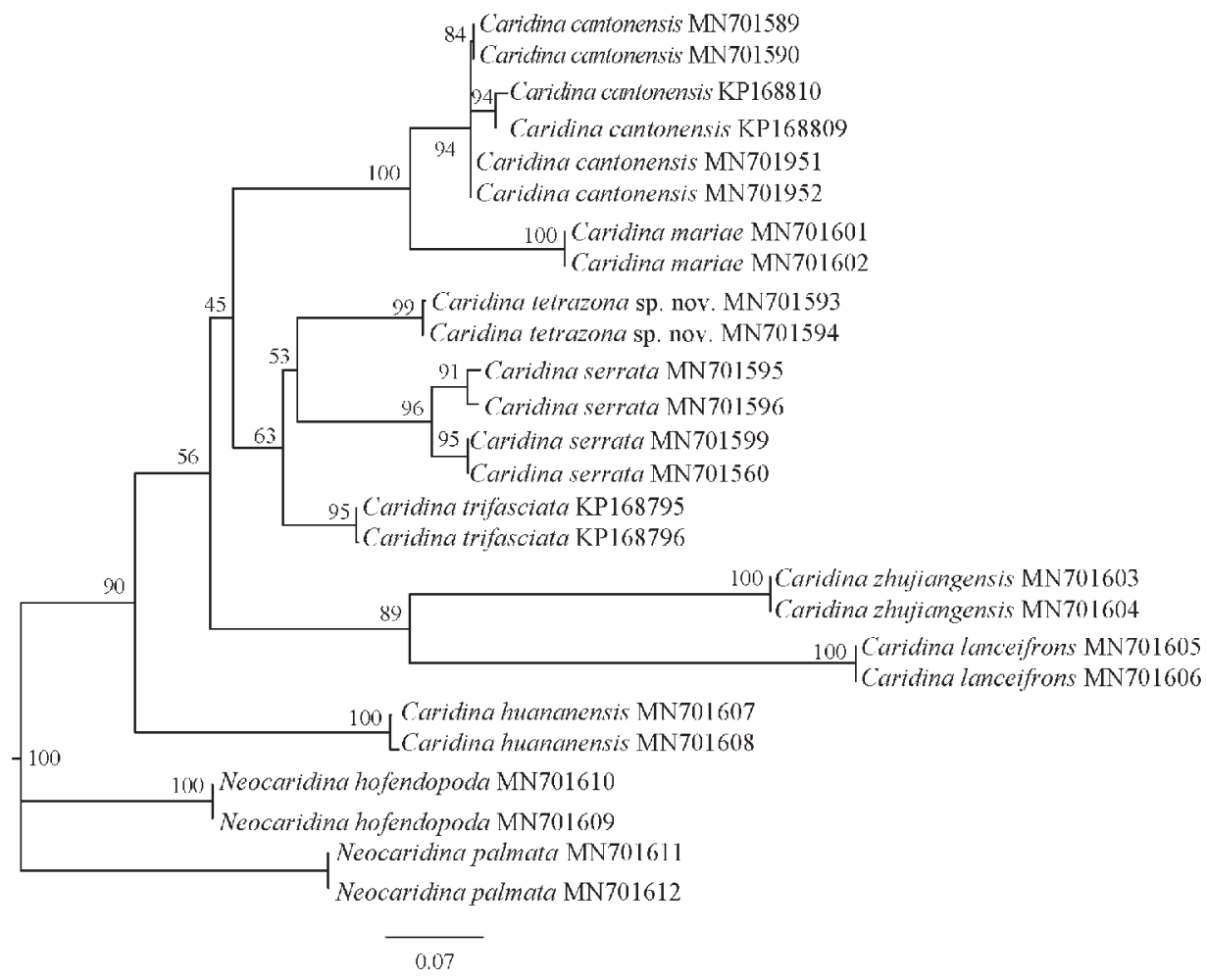

Figure 7. Phylogenetic tree (ML) based on COI gene fragments of 10 shrimp species of Caridina and Neocaridina (outgroups). Support values at the nodes represent bootstrap values for ML.

ecological tourism on the island. Monitoring changes in wild populations according to local legislation should also be intensified, and campaigns that promote environmental education and raising tourists' awareness of the importance of biodiversity should be encouraged.

\section{Acknowledgements}

This study was supported by the Special Fund for Central Public Welfare Research Institutes (Grant No. PM-zx097-201904-134), the Running Cost for Key Laboratory of Utilization and Breeding of Aquatic Resources in Tropical and Subtropical Areas, Ministry of Agriculture and Rural Affairs (Grant No. 9020190008) and the Investigation on Crustaceans in Priority Area of Mangrove Diversity Protection in Guangxi Zhuang Autonomous Region (Grant No. kh19051). We thank Dr. Chao Huang (University of New South Wales) for modifying the manuscript. Thanks are also due to subject editor Ingo Wehrtmann, copy editor Christopher Glasby and two reviewers (Yixiong Cai and Charles Fransen) for providing their valuable suggestions, which greatly improved the manuscript. 


\section{References}

Bouvier LB (1905) Observations nouvelles sur les crevettes de la famille des Atyides. Bulletin Scientifique de la France et de la Belgique 39: 57-134.

Bouvier LB (1925) Recherches sur la morphologie, les variations et la distribution systématique des crevettes d'eau douce de la famille des Atyidés. Encyclopédie Entomologique 4: 1-370.

Cai YX, Ng NK (1999) A revision of the Caridina serrata species group, with descriptions of five new species (Crustacea: Decapoda: Caridea: Atyidae). Journal of Natural History 33: 1603-1638. https://doi.org/10.1080/002229399299789

Chen QH, Chen WJ, Guo ZL (2018) Caridean prawn (Crustacea, Decapoda) from Dong'ao Island, Guangdong, China. Zootaxa 4399(3): 315-328. https://doi.org/10.11646/ zootaxa.4399.3.2

De Grave S, Smith KG, Adeler NA, Allen DJ, Alvarez F, Anker A, Cai YX, Carrizo SF, Klotz W, Mantelatto FL, Page TJ, Shy J-Y, Villalobos JL, Wowor D (2015) Dead Shrimp Blues: A global assessment of extinction risk in freshwater shrimps (Crustacea: Decapoda: Caridea). PloS One 10(3): e0120198. https://doi.org/10.1371/journal.pone.0120198

De Mazancourt V, Klotz W, Marquet G, Keith P (2018) Integrative taxonomy helps separate four species of freshwater shrimps commonly overlooked as Caridina longirostris (Crustacea: Decapoda: Atyidae) on Indo-West Pacific islands. Invertebrate Systematics 32: 14221447. https://doi.org/10.1071/IS18034

Folmer O, Black M, Hoeh W, Lutz R, Vrijenhoek R (1994) DNA primers for amplification of mitochondrial cytochrome c oxidase subunit I from diverse metazoan invertebrates. Molecular Marine Biology and Biotechnology 3(5): 294-299.

He ZJ, Feng ZJ, Li ZK (2004) Plant resources on Wanshan Islands in Zhuhai City, Guangdong Province. Subtropical Plant Science 33(2): 55-59.

Hebert PDN, Ratnasingham S, de Waard JR (2003) Barcoding animal life: cytochrome c oxidase subunit 1 divergences among closely related species. Proceedings of the Royal Society B: Biological Sciences 270 (suppl_1): s96-s99. https://doi.org/10.1098/rsbl.2003.0025

Huang H, You F, Lian JS, Zhang CL, Yang JH, Li XB, Yuan T, Zhang YY, Zhou GW (2012) Status and conservation strategies of the scleractinian coral community in the Wanshan Island at Pearl River Estuary. Marine Science Bulletin 31(2): 189-197.

Huang SH, Wang WC (2000) A conception of constructing the marine ecological park in Wanshan Islands, Zhuhai. Tropical Geography 20(3): 228-232.

Kalyaanamoorthy S, Minh BQ, Wong TKF, Haeseler AV, Jermiin LS (2017) ModelFinder: fast model selection for accurate phylogenetic estimates. Nature Methods 14(6): 587-591. https://doi.org/10.1038/nmeth.4285

Katoh K, Standley DM (2013) MAFFT multiple sequence alignment software version 7: improvements in performance and usability. Molecular Biology and Evolution 30(4): 772780. https://doi.org/10.1093/molbev/mst010

Kemp S (1918) Zoological results of a tour in the Far East. Crustacea Decapoda and Stomatopoda. Memoirs of the Asiatic Society of Bengal 6: 218-297.

Kumar S, Stecher G, Tamura K (2016) MEGA7: molecular evolutionary genetics analysis version 7.0 for bigger datasets. Molecular Biology and Evolution 33(7): 1870-1874. https:// doi.org/10.1093/molbev/msw054 
Liang XQ (2004) Crustacea, Decapoda, Atyidae. Fauna Sinica. Invertebrata 36: 1-375. [In Chinese with English abstract]

Liao WQ, Zhang JG, Huang HP (2000) Development of the tourism resources of the Wanshan Islands. Tropical Geography 20(2): 134-138.

Nguyen LT, Schmidt HA, von Haeseler A, Minh BQ (2015) IQ-TREE a fast and effective stochastic algorithm for estimating maximum-likelihood phylogenies. Molecular Biology and Evolution 32(1): 268-274. https://doi.org/10.1093/molbev/msu300

Ortmann AE (1894) A study of the systematic and geographical distribution of the decapod family Atyidae Kingsley. Proceedings of the Academy of Natural Sciences of Philadelphia 46: 397-416.

Ronquist F, Teslenko M, van der Mark P, Ayres DL, Darling A, Höhna S, Larget B, Liu L, Suchard A, Huelsenbeck JP (2012) MrBayes 3.2: efficient Bayesian phylogenetic inference and model choice across a large model space. Systematic Biology 61(3): 539-542. https:// doi.org/10.1093/sysbio/sys029

Stimpson W (1860) Prodromus descriptionis animalium evertebratorum, quae in Expeditione ad Oceanum Pacificum Septentrionalem, a Republica Federata missa, Cadwaladaro Ringgold et Johanne Rodgers Ducibus, observavit et descripsit. Pars VIII. Crustacea Macrura. Proceedings of the Academy of Natural Sciences of Philadelphia 12: 22-47.

Yam RSM, Cai YX (2003) Caridina trifasciata, a new species of freshwater shrimp (Decapoda: Atyidae) from Hong Kong. Raffles Bulletin of Zoology 5(2): 277-282. 